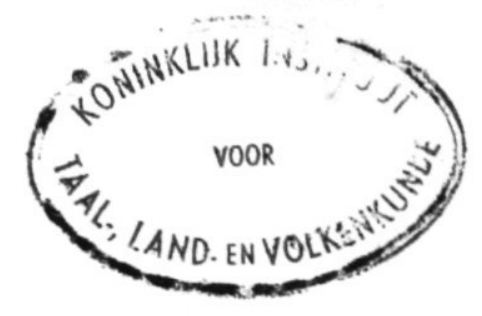

\title{
HINDOSTAANSE SURINAMERS IN AMSTERDAM
}

\section{INLEIDING}

\section{a. Aanleiding tot het onderzoek}

Het onderzoek werd door mij begonnen om twee met elkaar samenhangende redenen. In de eerste plaats werd mijn gewone nieuwsgierigheid geprikkeld doordat ik de indruk kreeg dat de Hindostaanse Surinamers zich nogal afzijdig hielden van de andere Surinamers in Nederland, wat betreft het verenigingsleven en andere georganiseerde samenkomsten. Daar mijn vrouw Creoolse is, had ik een vrij goed overzicht van wat zich onder de Surinamers in Amsterdam, althans zover het het milieu van studenten en in witte-boorden beroepen werkzamen betrof, afspeelde. Ik mocht aan mijn indrukken dus wel enige waarde toekennen. Bovendien was mij bekend dat in Den Haag de Hindostaanse Jongeren Vereniging 'Manan' niet alleen vanuit Den Haag zelf, maar vanuit heel Nederland, veel leden trok en een bloeiend bestaan leidde 1 .

De tweede reden was van meer academische aard. $\mathrm{Al}$ een aantal jaren volgde ik de Surinaamse migratie naar Nederland met het plan, nog eens een onderzoek in te stellen naar de factoren die de aanpassing van deze rijksgenoten beïnvloeden. Ik zou daartoe niet alleen de beschikking moeten hebben over een doordacht geheel van problemen en hypothesen, maar ook over een aanzet tot indicering. Om hierin enig inzicht te krijgen, moest ik mij wel oriënteren op een kategorie Surinamers die in bepaalde opzichten wel eens een aparte plaatst zou kunnen innemen.

\section{b. Materiaalverzameling}

De enige techniek die hiervoor geschikt leek was de observatie en dan vooral de observatie welke vanaf een geringe sociale afstand kon worden verricht. Te spreken van participerende observatie 
ging mij aanvankelijk te ver, daar ik niet wist of er een daartoe passende rol beschikbaar was ${ }^{2}$. Maar de mogelijkheden daartoe bleken al gauw in voldoende mate aanwezig. Ik besloot toen ook mij als onderzoeker niet bekend te maken. Het was voor mij betrekkelijk eenvoudig contact op te nemen met dat deel der H.S. * dat aan georganiseerde bijeenkomsten deelnam. Van daaruit ontstonden langzamerhand ook contacten in de informele sfeer van feestjes, visites e.d. Naarmate de contacten zich uitbreidden tekende zich ook vanzelf een rol voor de onderzoeker af. Zo werd $\mathrm{ik}$ al spoedig tot secretaris van de discussie-vereniging gekozen; formele rollen hebben overigens weinig betekenis zoals later nog zal blijken. Ook genoten - om een informeler voorbeeld te noemen - door de onderzoeker opgestelde sollicitatie-brieven een, naar ik vrees ongegrond, vertrouwen.

Wellicht is het wel ter zake hier te vermelden dat de psychische druk, die bij een dergelijk dubbelspel nu eenmaal ontstaat, mij persoonlijk zwaar is gevallen. Bovendien stelt deze techniek de onderzoeker weliswaar in staat zich op een unieke manier te verdiepen in de groepering die hij bestudeert, maar veel van het verkregen materiaal kan hij zonder vertrouwen te schenden niet aan derden mededelen. Hoe hier de grens getrokken moet worden is opnieuw een onoplosbaar probleem. In het bijzonder daar het een relatief klein aantal gemakkelijk te traceren personen betreft. Persoonlijk zal ik een dergelijk onderzoek, althans met verhulling van de onderzoekersrol ook niet meer ondernemen ${ }^{3}$.

Ik begon het onderzoek in februari 1966 en beëindigde mijn waarnemingen in het voorjaar I968. Al spreekt het vanzelf dat daarmede niet in één slag alle contacten met de groepering verbroken waren. In juli-augustus I968 werd het onderzoek afgesloten met het schrijven van dit artikel dat ik in het voorjaar van 1969 nog eens critisch heb herzien.

\section{c. Enkele termen en concepten}

Ondanks alle bezwaren die daar altijd tegenin gebracht worden, lijkt het mij ook dit keer weer niet mogelijk het geheel zonder vakjargon te stellen.

Ik beoog in dit artikel niet alleen een beschrijving van een aantal aspecten van het leven van H.S. in Amsterdam, maar heb

\footnotetext{
* In dit artikel wordt de term Hindostaanse Surinamers meestal afgekort tot H.S.; CREOOLSE Surinamers tot C.S.
} 
tevens voortdurend het doel voor ogen gehad, inzicht te krijgen in de migratie-situatie. Het perspectief van waaruit is waargenomen is dat van de aanpassing van deze migranten-groepering aan de Nederlandse omgeving. Het is daarom noodzakelijk dit perspectief iets nader aan te duiden en in te gaan op het begrip aanpassing.

In de Engelse literatuur over de Westindische migranten en bij ons in Gunawans studie over de Indonesische studenten, worden nogal eens vormen van aanpassing onderscheiden zoals adaptatie, accomodatie e.d., waarbij het indelingscriterium 'het streven' van de groep is ${ }^{4}$. Zowel Gunawan als Patterson wijzen erop dat zij deze vormen van aanpassing niet stationair zien, maar opvatten als stadia van een proces. Naar mijn mening wordt een analyse van het procesmatig-karakter van het aanpassingsverschijnsel echter juist belemmerd, door de sterke klemtoon die deze 'stadia' krijgen, waarbij voortdurend het gevaar ontstaat dat ze toch het karakter krijgen van (elkaar uitsluitende) vormen van aanpassing. Mijn bezwaren tegen deze terminologie gaan echter verder. In de eerste plaats vormen de Surinamers - ook de H.S. in Nederland - geen groep in de sociologische betekenis van het woord. Of men hen als sociale categorie of als collectiviteit wil opvatten, zal afhangen van de problemen waarvoor men zich gesteld ziet. In deze studie zijn in ieder geval de H.S. in Amsterdam als collectiviteit opgevat ${ }^{5}$. Zelfs binnen een bepaalde laag als bijv. de studenten, is het aantal personen met wie men regelmatig interactie heeft over het algemeen gering. Natuurlijk hebben zich binnen deze collectiviteit groepen gevormd, waarvan de leden wel interactie hebben. Maar over het algemeen vindt de communicatie onder de Surinamers in Nederland plaats via netwerken. Hieronder versta ik reeksen personen die met elkaar in communicatie staan maar geen directe onderlinge interactie onderhouden. In deze situatie lijkt het mij niet dienstig van groepseigenschappen uit te gaan. Maar ook voor individuen is de gebezigde terminologie m.i. minder geschikt en wel door de klemtoon die op 'strevingen' gelegd wordt. In de eerste plaats is het zeer moeilijk vast te stellen waar iemand naar streeft. Verbale uitingen zijn nogal eens sterk wisselend in de emotioneel nu eenmaal dikwijls gespannen migratie-situatie en niet zelden in opmerkelijke tegenstelling met het waarneembare gedrag. Een nog ernstiger bezwaar is m.i. dat het streven van het individu (ook bij de betrokken auteurs!) tevens in hoge mate als resultante van het aanpassingsproces wordt gezien ${ }^{6}$. Ik zou daarom aanpassing zoveel 
mogelijk als een proces willen zien. Om de gecompliceerdheid van dit proces te benadrukken en vooral te voorkomen dat het al te simplistisch wordt opgevat als een recht toe recht aan gebeuren, maak ik onderscheid naar 3 niveau's ${ }^{7}$ :

I. Het cognitieve niveau

2. Het evaluatieve niveau

3. Het niveau van de smaak/esthetica.

Ad I. - Onder het cognitieve vallen alle aspecten die te maken hebben met kennis-elementen, zowel van de Nederlandse samenleving als van de migranten-groepering 'waar men de weg moet leren vinden'. Dit heeft met name betrekking op doeleinden, middelen en verwachtingen.

Ad 2. - Onder het evaluatieve niveau versta ik opvattingen over hetgeen behoorlijk is: normen en waarden. Ik zal de term normen daarbij gebruiken voor opvattingen over het gedrag in concrete situaties (gedragsregels) terwijl waarden in meer algemene, abstracte zin worden opgevat. De term norm wordt hier alleen in evaluatieve zin gebruikt, norm in de zin van verwachting (expectation-norm) duid ik aan als verwachting.

Ad 3. - Met het laatste niveau, dat van de smaak, worden de voorkeuren voor bijv. muziek, voedsel e.d. aangeduid, die geen betrekking hebben op een moreel oordeel.

Vanuit dit schema is het niet nodig het aanpassingsproces als een ongedifferentieerd geheel te zien, waarbij de migranten zich unilineair van onaangepast naar aangepast zouden bewegen. Al vrij gauw ben ik er bij mijn onderzoek van uitgegaan, dat de aanpassing op deze drie niveau's niet synchroon behoeft te verlopen. Hoewel de aanpassing op de beide laatste niveau's een cognitieve aanpassing vóóronderstellen, is dit andersom zeker niet het geval. Veel gedrag van migranten kan m.i. juist verklaard worden door het ongelijkmatig verlopen van de aanpassing op de verschillende niveau's.

Behalve een onderscheid naar niveau's van aanpassing moeten wij ook nog een onderscheid maken 'naar de verschillende terreinen des levens'. Op lang niet alle terreinen is de druk van de omringende maatschappij om zijn gedrag en daarmede de verwachtingen, normen en waarden, waarop dat gedrag gebaseerd is, te herzien even groot. In de werksfeer zal de tolerantie ten opzichte van wat afwijkend gedrag in de Westeuropese maatschappij 
bijv. duidelijker geringer zijn, dan bij de vrijetijdsbesteding. Een enigszins volledige bestudering van de Surinaamse migranten zou behalve aan arbeid en vrijetijdsbesteding ook aandacht aan de gezins- en opvoedingssituatie moeten besteden. De waarnemingen waarop dit artikel berust, dat uiteraard geen enkele pretentie ten aanzien van volledigheid heeft, zijn vrijwel alle in de vrijetijdssfeer tot stand gekomen. $\mathrm{Al}$ heb ik getracht van daaruit zoveel mogelijk inzicht te verwerven, meer dan betrekkelijk willekeurig gekozen aspecten van het leven van H.S. in Amsterdam moet de lezer niet verwachten aan te treffen.

Een studie als deze biedt uiteraard geen enkele garantie voor de representativiteit. Met opzet vermeed ik dan ook in de titel van het artikel het lidwoord.

\section{d. De Hindostaanse Surinamers in Nederland}

De migratie van Hindostaanse Surinamers naar Nederland is een recent verschijnsel, dat pas de laatste jaren enige kwantitatieve betekenis heeft. Het is niet mogelijk exacte cijfers over de Surinaamse migratie te verkrijgen. Maar eind I 968 kan het aantal Surinamers in Nederland op ongeveer 18.000 worden gesteld 8 . Ongeveer $10 \%$ van hen is H.S.

Vergeleken met de Creoolse Surinamers, die een migratie-traditie hebben die tot in de Ige eeuw teruggaat, doen zich enkele verschillen voor. Zo richten de H.S. zich bij voorkeur op Den Haag, terwijl de C.S. zich duidelijk concentreren in Amsterdam. Daardoor komt dat van de ca 9.0oo Surinamers in Amsterdam er slechts ongeveer 450 H.S. zijn. Voor belangrijke manifestaties van H.S. karakter gaat men dan ook naar Den Haag. Dit wordt voor de Islamieten onder de H.S. nog versterkt, doordat in Den Haag wel (twee) moskeeën zijn maar in Amsterdam niet.

De bemoeienis met en de sociale controle op de H.S. vanuit Suriname is aanzienlijk sterker dan bij de C.S. gebruikelijk is. Hiervoor zijn verschillende redenen aan te wijzen. In de eerste plaats is de sociale controle bij de H.S. ook in Suriname sterker. Men denke maar aan het sterke ouderlijke gezag en de hechte familiebanden. In de tweede plaats is de H.S. migratie naar Nederland een vrij recent verschijnsel waardoor de verblijfsduur gemiddeld korter is dan bij de C.S. en de omvang van de groepering kleiner. Twee factoren die de sociale controle vergemakkelijken. Tenslotte, we zullen het later in dit artikel nog ter sprake brengen, is de drang tot terugkeer groter dan onder de C.S. 
Een ander gevolg van de beperkte omvang van de groepering is, dat de sociale differentiatie (nog?) niet geleid heeft tot interne differentiëring binnen de groepering en b.v. tot afzonderlijke verenigingen. De sociale differentiëring is er al wel, al is de samenstelling der H.S. in Nederland wel veel homogener dan van de C.S. Het is vooral in Amsterdam moeilijk hierop een goed zicht te krijgen. Het aantal arbeiders is echter duidelijk gering. Het aantal employé's, onderwijzers e.d. is opvallend groot. Het betreft hier nogal wat jonge employé's (niveau Mulo opleiding) die nog uitzicht hebben op stijging via het volgen van cursussen e.d. De grens naar de zijde der studenten is dan ook niet scherp te trekken, temeer niet daar ze zich zelf nogal eens als student beschouwen. Ook omvat de groepering enkele middelbare scholieren en volgers van een beperkte cursus of opleiding, die naar het Nederlandse gebruik eerder scholier dan student genoemd zouden worden. Tenslotte de studenten, waartoe ik ook de H.T.S-ers, studerenden voor M.O.-acten e.d. reken. Naar mijn schatting moet de helft van de H.S. tot de employé's gerekend worden. De studenten en arbeiders schat ik gelijkelijk op ongeveer $25 \%$.

\section{VRIJETIJDSBESTEDing}

\section{a. Algemeen}

Een stad als Amsterdam biedt een grote verscheidenheid aan mogelijkheden om de vrije tijd door te brengen. Dit geldt zowel voor de aard der activiteiten die men kan ondernemen, als voor de personen met wie men de vrije tijd kan doorbrengen. Vooral op de personen bij wie men zich in de vrije tijd aansluit heb ik het oog gericht.

Als wij een indeling maken naar personen met wie men (overwegend) zijn vrije tijd doorbrengt, krijgen we in ieder geval de volgende categorieën:

A. Zij die overwegend contact hebben met Surinamers.

I. Zij die hun contacten overwegend met H.S. hebben.

2. $\mathrm{Zij}$ die hun contacten overwegend met C.S. hebben.

B. Zij die (overwegend) contact hebben met Nederlanders.

Dit schema is logisch niet volledig, maar het is met opzet beperkt tot de categorieën die bij mijn onderzoek een rol hebben gespeeld. De mengcategorieën, die men zou verwachten en waarnaar ik 
ook heb gespeurd, heb ik eigenlijk niet aangetroffen, zelfs niet bij de enkele gemengde gehuwden. Nu zijn de aantallen niet zo groot en het gaat wat ver te beweren, dat zulke personen in het geheel niet voorkomen. Een opvallend gering aantal zal dit m.i. echter wel zijn. Bijzonder opvallend is dat in Amsterdam gedurende de bestreken twee jaar (I966-'68) ook de kategorie 'overwegend met C.S.' (vrijwel) niet voorkwam. Dit laatste in tegenstelling tot mijn verwachtingen. Ik ging nl. aanvankelijk uit van de veronderstelling dat de contacten van de H.S.-migrant zich zouden verwijden tijdens het aanpassingsproces. De vriendenkring zou zich dan van Ar via A2 naar B ontwikkelen.

Een interessante observatie was het plotseling op te merken dat ook ik zelf, en tot op zekere hoogte zelfs mijn vrouw, er niet in slaagden gedurende dezelfde tijdsperioden onze vrije tijd (regelmatig) door te brengen met onze H.S.-kennissenkring zonder onze andere Surinaamse en Nederlandse kennissen te verwaarlozen. We hebben hier dus met relatief gesloten kennissen- en vriendenkringen te maken.

Een verklaring hiervoor is te vinden in de functies, die vrienden en kennissen voor de H.S. vervullen. Voor de pas aangekomene is het zaak zo snel mogelijk enkele mensen te vinden die voor huisvesting, werk, e.d. zorgen. De eerst aangewezenen daartoe zijn familieleden. Vanuit dit contact met familieleden en (of) vrienden, die hij al in Suriname kende, groeit zijn netwerk. Daar de kern daarvan bijna altijd familiaal - in de ruime Surinaamse zin ${ }^{9}$ bepaald is, leidt dit automatisch tot een concentratie binnen de H.S. groepering. De sociale controle vanuit Suriname door ouders en andere verwanten uitgeoefend, versterkt dit. Vooral kinderen uit één gezin ontbreekt het niet aan vermaningen, voor elkaar zorg te dragen. Deze controle wordt - naar Nederlandse maatstaven - in hoge mate aanvaard. Uit onwetendheid met de Nederlandse situatie, bijv. wat betreft huisvesting, worden vanuit Suriname dikwijls eisen gesteld, die in feite niet vervuld kunnen worden. Maar men tracht er bijna altijd zo goed mogelijk aan te voldoen. Zelfs mensen die tegenover mij verklaarden dit absurd, ouderwets of zoals de aanduiding in het idioom van deze subcultuur luidt 'orthodox' te vinden, hielden er wel degelijk rekening mee.

Een tweede reden is gelegen in de sterke behoefte aan een vertrouwde schuilplaats, waar men kan bijkomen van de dagelijkse druk die vooral in het begin groot is. Hoe vertrouwder deze omgeving is, des te beter kan men zich zelf zijn. Hoe sterker het 
gevoel van onder ons zijn, met de eigen Hindostaanse muziek, eigen voedingsgewoonten, vertrouwde opvattingen over de omgang tussen mannen en vrouwen etc., hoe veiliger men zich voelt. Ook dit leidt tot een voorkeur voor contacten binnen de eigen ethnisch-culturele groepering.

Het is niet zo, dat men zich moet voorstellen dat dit voor alle H.S. opgaat. Er zijn ook mensen die zich vrij nadrukkelijk en bruusk, al bij aankomst in Nederland, distanciëren. Zoals één van hen mij zei: "Ik ben niet naar Nederland gekomen om zoveel mogelijk te blijven verkeren in de familie-ruzie's, burenveten en eindeloze visites van verre neven en nichten, waar ik m'n hele leven al ingezeten heb". Ik zou niet kunnen aangeven met behulp van welke aanwijzingen men een dergelijke houding kan voorspellen. Een drietal indicatoren die ik hanteerde om afstand tot het H.S. milieu in Suriname aan te geven, te weten: het niet (kunnen) spreken van Hindi; het niet Hindostaans gehuwd zijn en het (bij gelegenheid) eten van rundvlees (voor Islamieten varkensvlees), geven wellicht bij ruimer statistisch gebruik uitsluitsel. Maar niet in zo strikte zin als ik had gehoopt, daar ik deze eigenschappen ook heb aangetroffen bij mensen, die wel een duidelijke oriëntering op H.S. contacten hadden. De overgang tussen de categorieën A en B zoals ik die heb aangetroffen toont een relatief abrupt en absoluut karakter.

Categorie A2 kwam - het werd al opgemerkt - zo goed als niet voor. Een verklaring voor dit verschijnsel, dat mogelijk een specifiek Amsterdamse situatie weerspiegelt, hoop ik in het laatste hoofdstuk te geven. Dat de overgang tussen A en B mij min of meer ontsnapt is, ligt aan de beperkingen die het onderzoek met zich meebracht. Het is in een stedelijke samenleving nu eenmaal onmogelijk een wat groter aantal mensen met de techniek der participerende observatie in hun vrijetijdsbesteding te volgen, tenzij ze regelmatig een gemeenschappelijke vorm van vrijetijdsbesteding hebben. Dat houdt in dat het blikveld van de onderzoeker in sterke mate beperkt wordt.

Het was voor mij noodzakelijk me vooral te richten op die personen, die aan georganiseerde activiteiten deelnemen of hebben deelgenomen. Dit leidt er uiteraard toe, dat bepaalde aspecten onderbelicht worden. Ten dele heb ik getracht deze onderbelichting te compenseren door aan de categorieën die wat minder nadrukkelijk aan de georganisserde activiteiten deelnemen - arbeiders, vrouwen - extra aandacht te geven. Ik heb ook enkele 
mensen opgespoord, die in het geheel niet deelnamen en dit ook nooit hadden gedaan. Ook met hen werd een aantal gesprekken gevoerd, maar daarmede wordt het onderzoek natuurlijk niet representatief. De lezer zij op dit punt dus nogmaals gewaarschuwd. Het meest hindert mij hierbij, dat ik juist op de overgang van het wel deelnemen naar het niet-deelnemen waarvoor ik mij bijzonder interesseerde, niet veel zicht heb gekregen.

\section{b. De vereniging}

In Amsterdam functioneerde toen ik mijn waarnemingen deed één echte H.S.-Vereniging; het oorspronkelijk als zuivere discussiegroep opgerichte 'Retorica'. Het is één van de vele groepjes, clubs en verenigingen die door Surinamers in Nederland opgericht worden. Meestal hebben deze verenigingen slechts een kort leven. Zelfs de verenigingen die tot bloei komen verlopen plotseling na enige jaren weer. Een karakteristieke trek van H.S.-verenigingen in Nederland is hun poging om zich als Hindostaanse Vereniging toch algemeen op te stellen en te presenteren. Zo tooit de filmliga, die zich tot de H.S. richt en regelmatig Indiase films vertoont, zich met de naam 'West Indian Film Society'. Ook de grote Haagse vereniging 'Manan', van onweerlegbaar Hindostaans karakter, noemde zich officieel 'Surinaamse Jongeren Vereniging Manan'. Het is m.i. een typerende trek, die duidelijk maakt hoe zeer de H.S. gekenmerkt worden door enerzijds een sterke behoefte aan 'eigenheid' en 'beslotenheid' en zich anderszijds als Surinamers wensen te zien. Ook 'Retorica' heeft zich van begin af aan nadrukkelijk open gesteld voor allen, ongeacht religie of ras. Van deze vereniging zijn ook altijd wel enkele niet H.S. lid geweest, wat mijn entree, als eerste Nederlander, zeker gemakkelijk maakte. Aan de leden van deze vereniging heb ik veel te danken. Als hun bereidheid tot contact niet zo groot was geweest, had dit artikel niet geschreven kunnen worden.

Gezien het grote aantal Surinaamse verenigingen en clubs welke in Nederland met over het algemeen weinig succes worden opgericht, is het de moeite waard na te gaan, waarom de oprichting van 'Retorica' wel succesvol is verlopen. Daarvoor zijn drie redenen aan te voeren:

I. Het teruglopen van de Haagse vereniging 'Manan', waardoor enkele actieve Amsterdamse leden naar mogelijkheden om gingen zien om in Amsterdam een vereniging te stichten. 
2. Het toenemend aantal H.S. in Amsterdam waardoor er voortdurend (meest jonge) mensen waren, die behoefte hadden aan een ontmoetingspunt.

3. Er was al eerder in Amsterdam een H.S. vereniging opgericht maar deze was niet van de grond gekomen. Deze vereniging had volgens de meeste informanten vooral het karakter gehad van een tegenwicht te scheppen tegen het aan de VHP 10. gelieerde 'Manan' door leden van de Actie-groep 11. Hiervan kwam een deel en bloc over naar de zich nadrukkelijk neutraal opstellende nieuwe vereniging, die daardoor onmiddellijk een zekere omvang kreeg.

Met dit laatste punt zijn we bij een van de opmerkelijkste kenmerken van de Surinaamse verenigingen in Nederland beland. $\mathrm{Al}$ deze verenigingen zijn nl. meer of minder nauw gelieerd aan een Surinaamse politieke partij. Zelfs een vereniging waar een sterke ideologie van neutraliteit onder de leden heerst, krijgt toch het gezicht van meer of minder tot deze of gene politieke partij te behoren. Ten dele omdat de leidende figuren inderdaad altijd toch met een politieke kleur rekening houden en de vereniging zo langs politieke lijn trachten te domineren. Zo is 'Retorica' tijdens de onderzoeksperiode duidelijk onder invloed van de Actie-groep gekomen. Ten dele krijgt men ook van buitenaf een gezicht opgeplakt omdat men anders niet weet hoe er tegenaan te kijken. $\mathrm{Zo}$ is mijzelf meermalen door VHP-ers gevraagd waarom ik sympathie had voor de Actie-groep, lang voor ik besefte hoe zij ertoe konden komen mij met een Surinaamse Politieke Partij te associëren. En dus ook voordat ik voldoende in de groepering was ingevoerd om dergelijke associaties te kunnen voorkomen.

De inhoudelijke verschillen tussen VHP en Actie-groep zijn zeer gering. Het zijn meer combinaties van personen dan politieke partijen in de Europese zin van het woord. Het voornaamste geschilpunt tijdens mijn onderzoek was het wel of niet aangaan van een coalitie met PENGEL's NPS. De Actie-groepers keerden zich hevig tegen deze coalitie en verweten de VHP dat haar verbroederingspolitiek PENGEL de gelegenheid gaf het Hindostaanse bevolkingsdeel ongestraft achter te stellen bij de Creolen. Hoe weinig hierbij concrete politieke bezwaren in het geding waren bleek wel uit de coalitie welke na de verkiezingen van r968 tot stand kwam: een coalitie van NPS en Actie-groep. ${ }^{12}$ Het ontstaan van afsplitsingen zoals de Actie-groep van de VHP komt dan ook meer voort uit het bestaan van persoonlijke conflicten tussen de leidende figuren binnen één partij dan uit verschillen van politiek inzicht. Daarbij ontstaan wel kettingreacties; met name kiezen families en bloc voor de ene of de andere partij. Het horen 
van iemands familienaam is dan ook dikwijls voldoende om zijn politieke kleur te kennen.

Interessant daarbij is een andere correlatie n.l. tussen richtingen in het Hinduïsme. In Suriname bestaat een meer rechtzinnige richting 'Senatam Dharm' en een hervormingsgezinde richting 'Arya Samaj'. De VHP is met de eerste, de Actie-groep met de tweede geassocieerd.13 Enkele dynamische studenten in Amsterdam behoorden tot de Arya Samaj en waren bovendien familiaal met de Actie-groep verbonden. $Z$ ij vormde een actieve kern van Actie-groepers in Amsterdam, die 'Retorica' gedurende het laatste jaar van mijn onderzoek domineerden. Hun verzet betrof echter weinig concrete politieke punten. Een links-radicale richting moet men er ook zeker niet in zien. De figuur van JAGAN bijv. sprak de Actie-groepers net zomin aan als de VHP-ers. Beide partijen streven naar een democratische, maar - om de Nederlandse term te gebruiken - verzuilde opbouw van Suriname. Tussen het besloten houden van de eigen groep en het bevorderen van het meer algemene Surinaamse belang ziet men geen tegenstelling. Integendeel, vanuit de eigen groep wil men in samenwerking met anderen het land opbouwen. Hoe beter men zichzelf is, des te groter kan de bijdrage zijn aan de Surinaamse samenleving, is daarbij de redenering.

Het spreekt wel haast vanzelf dat de politieke rivaliteit ook de waarnemingen en dus de informaties beïnvloedt. Zo vertelde mij één van mijn vrienden, die over het geheel genomen een goed informant was, mij eens van een bepaald vriendenclubje dat zij zeer 'orthodox' en 'racistisch' waren en dan ook nooit Surinaams zouden spreken maar altijd Hindi. Toevallig was ik enige malen in de gelegenheid dit clubje op kaartmiddagen te observeren en een redelijk nauwkeurige schatting te maken van de frequentie van de gesproken talen. Dit bleek voor $50 \%$ Surinaams te zijn en de overige tijd ongeveer gelijk op Nederlands en Hindi. Pas later toen ik wist dat enkelen uit dit clubje sterke familiale banden hadden met de Actie-groep kon ik de opmerking van mijn informant - een vurig VHP-er - in het juiste perspectief zien.

De formele activiteiten van de H.S.-verenigingen, dus ook van 'Retorica' zijn op zichzelf weinig verrassend en opwindend. Primair is dat men een vaste gelegenheid biedt tot gezellig verkeer, daarbij organiseert men van tijd tot tijd een lezing. Het karakter van deze verenigingen kan echter het beste begrepen worden vanuit de positie die de leiders innemen. Van die gezichtshoek uit zal ik het dan ook trachten duidelijk te maken.

\section{c. Leiderschap}

Bij een collectiviteit als de H.S. zijn geen algemeen aanvaarde leiders aan te wijzen. Toch is het voor ieder die zich maar even met H.S. bezig houdt duidelijk, dat er bepaalde personen zijn met een grote invloed. Bepaalde namen hoort men geregeld, naar bepaalde personen worden mensen die iets te vragen hebben, zoals $\mathrm{ik}$, verwezen. Als gewone groepsleden iets willen organiseren bijv. 
een Sinterklaasavond, dan moeten zij dat via een dergelijk invloedrijk persoon doen. Alleen als hij het initiatief overneemt, komt er voldoende publiek, verschijnt de muziekgroep op de afgesproken tijd e.d. In hoeverre zijn dergelijke figuren nu als leiders te zien? Om dit vast te stellen lette ik allereerst op hun positie bij georganiseerde activiteiten, met name in het verenigingsleven. Daarbij bleken zij inderdaad een belangrijke rol te spelen. Voortdurend vindt men dezelfde namen in besturen, bij ondertekenaars van manifesten etc. Een complicerende factor daarbij was echter dat ik in formele rollen, bijv. als bestuurslid, ook personen aantrof zonder persoonlijke invloed. Zij vervullen een dergelijke positie een tijdlang en verdwijnen dan weer naar de achtergrond. Tijdens vergaderingen kwam het verschil tussen de leidersfiguren en degenen, die min of meer toevallig in het bestuur zaten duidelijk naar voren. De leiders spraken langer en vaker en wisten (meestal) hun inzichten geaccepteerd te krijgen. Lukte het een leider niet op een bepaald punt zijn zienswijze ingang te doen vinden, dan leidde dit tot langdurige tumultueuze vergaderingen, die meestal zonder beslissing eindigden ... de zaak werd aangehouden. Van gewone groepsleden, ook al zaten zij in het bestuur, werden heel vaak voorstellen verworpen of zelfs met een grapje afgedaan. Juist omdat het leiderschap weinig geformaliseerd is, is het niet eenvoudig aan te geven hoe het functioneert. Ik zal het daarom vanuit verschillende aspecten benaderen door achtereenvolgens na te gaan: welke eigenschappen de prominenten van de gewone groepsleden onderscheiden, in hoeverre de volgelingen afhankelijk zijn van de leiders, en tenslotte welke functies de groepering voor de leiders vervult.

Een kenmerkend verschil tussen een leidersfiguur en een gewoon groepslid is dat de eerste een veel uitgebreider en ook veel gevarieerder vrienden- en kennissenkring heeft. De grotere reikwijdte van zijn contacten is min of meer vanzelfsprekend ${ }^{14}$; de veel gevarieerder kennissenkring eist enige toelichting.

De directe vriendenkring van een persoon wordt gekarakteriseerd door in Nederland aanwezige familieleden, de leeftijd en het opleidings- of beroepsniveau. Bij leiders is dat veel minder het geval. Zij hebben hun contacten verspreid door de gehele groepering. Deze uitgebreide en gevarieerde kennissenkring is soms reeds in Suriname opgebouwd. De overeenkomst met wat GunAwAN over het leiderschap onder de Indonesische studenten zegt is opvallend groot. Zo is het ook hier zo dat: "gewone groepsleden 
geen toegang hadden tot dit leiderschap. Nieuw aangekomenen daarentegen maakten wel kans onmiddellijk in het leiderscorps te worden opgenomen, mits zij een aanhang achter zich hadden, die zij ... reeds voor hun vertrek hadden verworven" ${ }^{15}$. Het belang van een grote kennissenkring voor hun positie wordt door de leiders scherp ingezien. Ze besteden aan deze persoonlijke contacten dan ook veel tijd en energie. Ook leggen zij lijsten aan van zoveel mogelijk adressen waarop nieuw aankomenden c.q. verhuizenden worden bijgeschreven. Bij een druppelsgewijs verlopende migratie als de Surinaamse, die bovendien veel dikwijls verhuizende inwonenden telt, is het beschikken over zoveel mogelijk adressen voor ieder die iets wil organiseren van groot gewicht. Een grote kennissenkring werkt hierbij cumulatief.

Wat bindt de volgelingen nu aan de leiders? Deze binding berust op het vermogen van deze leiders om groepsactiviteiten te organiseren. Nu zou men daarbij kunnen denken dat vooral diegenen van hen afhankelijk zijn voor wie groepsactiviteiten erg belangrijk zijn. De wonderlijke situatie doet zich echter voor, dat dit er slechts weinigen zijn. Onder hen die pas zijn aangekomen en hier geen of weinig familiale banden hebben doet zich veelal een sterke behoefte gevoelen aan een vorm van georganiseerd groepsleven. De formele rollen worden dan ook niet zelden door betrekkelijke nieuwkomers vervuld, die overigens geen enkele invloed hebben. Al spoedig echter kunnen de meesten zich ook wel zonder de georganiseerde activiteiten redden en al nemen zij er van tijd tot tijd aan deel, erg belangrijk zijn ze niet voor hen ${ }^{16}$. Het is dan ook onmogelijk een goede organisatie op te bouwen die ook werkelijk functioneert langs formele lijnen, met jaarvergaderingen en contributies. Daarom juist blijven ook de formele organisaties sterk afhankelijk van het op persoonlijke eigenschappen berustende leiderschap. Voor feestavonden, en bijv. een spreekbeurt van een bijzondere gast uit Suriname kan men een volle zaal bijeenbrengen. Er wordt dan ook zeer bewust weinig klemtoon gelegd op het formele lidmaatschap. Iedereen is welkom, hoe meer mensen hoe beter. De financiering van wat officieel een vereniging met contributies en een kas is, is dan ook in feite gebonden aan een verloting op een feestavond, de verkoop van roti's in de pauze e.d., waarop winst wordt gemaakt. In deze situatie is men derhalve van de leiders afhankelijk juist omdat de ondernomen activiteiten niet zovéél waarde voor de leden hebben dat zij er zich ook actief voor inzetten. Dit betekent overigens ook, 
dat de meeste leden slechts in beperkte mate van de leiders afhankelijk zijn. Zouden de groepsactiviteiten voor de leden van groter belang zijn, dan zou het groepsleven ook hechter worden en het leiderschap een sterker en waarschijnlijk meer geformaliseerd karakter krijgen.

Een tweede factor die althans een aantal leden van de collectiviteit aan de leider bindt, is zijn kennis van de migratie-situatie. Deze kennis van de migratie-situatie berust enerzijds op het beschikken over contacten met en informatie over Suriname, anderzijds op een - zeker op cognitief niveau (instrumentele relaties) goede zo niet uitstekende aanpassing aan de Nederlandse samenleving. Deze aanpassing moet men zich bepaald niet alleen passief maar ook actief voorstellen. Zo zijn er leiders die een goed oog hebben voor de mogelijkheden welke er in de verzuilde opbouw van onze welzijnszorg zitten voor personen of organisaties die zich levensbeschouwelijk onderscheiden. Men weet zich dan tactisch op zijn 'religieuze plichten' te beroepen, waarvan de brave ambtenaar slechts een vage voorstelling heeft en ten minste in enkele mij bekende gevallen met opmerkelijk succes. Een dergelijk goed ingevoerde leider is voor velen een geschikte raadsman bij vele problemen.

$\mathrm{Nu}$ vergt deze functie een aantal eigenschappen van de leider, die moeilijk met elkaar te verenigen zijn. Hij moet cognitief goed aangepast zijn, zonder dat hij op het evaluatieve en esthethicavlak al te zeer vernederlandst is. Als dit laatste eenmaal gebeurt, als de leider te lang in Nederland verblijft en zo langzamerhand dezelfde frustraties in het contact met zijn pas aangekomen landgenoten gaat ondervinden als de Nederlanders, dan is zijn tijd voorbij en verdwijnt hij langzaam aan naar de achtergrond. Vooral in deze fase van leiderschap zijn agressieve uitingen op het verbale vlak tegen de Nederlandse samenleving moeilijk te vangen in de gebruikelijke verklaringen, dat dit soort uitingen het resultaat is van ondervonden frustraties. Het is in deze gevallen veeleer een uiting van schuldgevoel over een vlot verlopend aanpassingsproces en een poging om zijn solidariteitsverplichtingen ten opzichte van de collectiviteit na te komen. Men zou het zo kunnen omschrijven, dat een leider niet zo goed aangepast moet zijn dat hij de dagelijkse frustraties en onzekerheid van zijn mede-migranten niet meer zelf aan den lijve ervaart, maar weer wel zo goed dat hij een goed overzicht heeft van de mogelijkheden om ze te boven te komen.

De derde benadering van het leiderschap onder de H.S. is ons 
af te vragen wat voor functies de groepering vervult voor de leider. Wat voor vruchten plukt hij van zijn inspanningen, of is hij iemand met sterk altruïstische karaktertrekken? Dit laatste is niet het geval. Hoewel hij zeker bereid moet zijn om iemand te helpen, is het ook weer geen man die zijn eigen belang uit het oog verliest. In persoonlijke gesprekken hebben deze leiders ook niet de pretentie voor altruïstisch door te gaan. De activiteiten worden direct of indirect ondernomen met het oog op de politiek in Suriname. Aan de ene kant verricht men zijn activiteiten min of meer officieus om de H.S. in Nederland zo sterk mogelijk te binden aan een politieke partij in Suriname; in dit geval dus VHP of Actie-groep. Enkele leiders die dezelfde oriëntatie hebben, vormen daarbij een clique. Aan de andere kant moet de formele organisatie hier in Nederland hem de gelegenheid geven de aandacht van de hogere leiders op zich te vestigen. Hij moet kunnen spreken namens: "De H.S. verenigd in ...". Goede pers-contacten zowel in Nederland als in Suriname moeten er dan verder voor zorgen dat zijn naam een zekere bekendheid krijgt. De Nederlandse pers, die door de Surinaamse pers weer gretig geciteerd wordt, beseft niet half welke rol haar daarbij is toegedacht! Men moet daarbij niet vergeten dat men in Suriname moeilijk of niet kan weten hoe groot en effectief een bepaalde organisatie in Nederland eigenlijk is. Er heerst dan ook van tijd tot tijd een ware proliferatie van z.g. formele organisaties allemaal drijvend op een klein aantal steeds dezelfde personen, die hierin voortdurend een platform vinden of althans zoeken. De climax wordt bereikt in die 'verenigingen' waar alleen een zichzelf coöpterend bestuur aanwezig is!

De werkelijke betekenis van de door de besturen uitgegeven verklaringen, de effectiviteit van hun leiderschap, is moeilijk vast te stellen. Er zit een binnenwaarts aspect in - hoe sterk is de positie ten opzichte van de eigen collectiviteit - en een buitenwaarts - hoe sterk weet een bepaalde leider de buitenwereld de indruk te geven dat er een brede aanhang achter hem staat. Deze beide aspecten kunnen, maar behoeven niet parallel te lopen. Een sterke band met bepaalde personen in het perswezen of politici kan buitenwaarts een grote invloed geven, zonder dat er sprake is van een grote invloed in de gewone contacten van alle dag. In dit verband is het begrijpelijk dat de leiders altijd een zeer sterke klemtoon leggen op de solidariteit naar buiten toe. In een bepaald geval had een leider een verklaring afgelegd, die achteraf binnenwaarts grote tegenstand ontmoette; er was echter niemand die eraan dacht deze oppositie ook bijv. via een ingezon- 
den brief of iets dergelijks, aan de buitenwereld waar deze verklaring was afgelegd, kenbaar te maken.

In het algemeen zijn de leiders in hoge mate vrij van controle van de collectiviteit wanneer zij naar buiten optreden. De meeste van de leden hebben voor dit optreden slechts een geringe belangstelling. Voor hen zijn de steun en de contactmogelijkheden in het alledaagse leven van veel groter belang. Daar de buitenwereld over het algemeen weinig of geen contact heeft met de collectiviteit omdat ze òf ver weg zit, òf uit Nederlanders bestaat, zijn de mogelijkheden voor de leiders groot om die mededelingen te doen, die hen op een gegeven moment juist voorkomen.

Dit kan tot een merkwaardige tegenstelling leiden tussen de mededelingen over eenzelfde gebeurtenis zoals die intern en aan buitenstaanders gedaan worden. Een aardig voorbeeld hiervan is te geven via de dissertatie van GunAwan. Hij vermeldt ${ }^{17}$, op zijn beurt refererend aan een persbericht, dat blijkens een enquête onder Surinaamse studenten gehouden door de VSSA $1875 \%$ bedekt of openlijk gediscrimineerd was bij het zoeken naar kamers. $\mathrm{Nu}$ was ik zijdelings bij deze enquête betrokken omdat ik ook een formulier had gehad. Na enige tijd had ik de organisatoren dan ook gevraagd hoe het ermee stond. Mij werd toen verteld, dat de enquête een volkomen mislukking was geworden door de geringe medewerking van de Surinaamse studenten. De enige conclusie die men intern meende te kunnen trekken, was dat er een volslagen gebrek aan solidariteit en samenwerking bestond. Dit was geen belemmering om tegenover de buitenwereld een verklaring af te leggen, waarin men een geheel andere indruk wekte!

\section{Tegenstellingen onder de Hindostaanse Surinamers}

Er zal wel geen groepering bestaan zonder tegenstellingen en conflicten. Dat zich ook onder de H.S. conflicten voordoen is opzichzelf dus niet zo interessant. Wel interessant is te zien welke punten aanleiding geven tot conflicten, omdat hierdoor duidelijker wordt waar voor de H.S. zelf de belangrijkste verschillen en overeenkomsten liggen. $\mathrm{Nu}$ is in de Surinaamse cultuur (in alle varianten) een veel grotere expressiviteit geoorloofd dan in de Nederlandse. Met name bestaat er een veel geringere rem op het in krachtige bewoordingen uiten van agressieve gevoelens. Het is dus niet zo moeilijk conflicten te signaleren. Veel moeilijker is het enig inzicht te krijgen in de achtergronden en de oorzaken. Zelfs daar waar van bepaalde personen alom bekend was, dat ze een 
diepgeworteld conflict hadden dat telkenmale tot uitbarsting kwam, kon niemand mij uitleggen waar het nu eigenlijk om ging. Bovendien was ik aanvankelijk erg voorzichtig met het stellen van vragen over conflicten. Later toen ik de ernstige van de minder ernstige had leren onderscheiden en gewend was aan de soms uiterst venijnige roddel binnen de groepering, die mij in het begin nogal onthutste, werd ik daar aanzienlijk vrijer in.

Een kenmerkende verklaring mij voor persoonlijke conflicten gegeven was wel 'dat het nog uit Suriname stamde'. Daar er slechts een beperkt aantal personen is dat inderdaad erg actief is in deze conflicten, zijn het bijna bij iedere ruzie dezelfde personen die de hoofdrollen spelen. Wat deze conflicten groot, langdurig en gecompliceerd maakt is het proces van clustervorming van bepaalde personen, die elkaar meestal gaan steunen bij een conflict maar dat niet per sé behoeven te doen. Zo werd de discussie-vereniging een tijd lang gekenmerkt door hevige conflicten tussen twee partijen waarbij de ene gekarakteriseerd werd door: VHPgezindheid, iets oudere leeftijdsamenstelling, en een beroep uitoefenend; de ander door Actie-groep-gezindheid, wat jongere leeftijdsamenstelling en student zijn. Bepaalde personen zijn door familiebanden met de VHP verbonden, dat bleek bij dit conflict meer relevant dan de maatschappelijke positie: werkend of studerend. Hoewel er tussen familieleden vaak onenigheid heerst, is de familieband toch meestal doorslaggevend als er bij een conflict in wijder verband partij gekozen moet worden. Dit is echter geen strikte wet; bij een ander conflict weet ik dat bepaalde familieleden eenvoudig het terrein van de strijd meden om geen keuze te hoeven doen. Deze mogelijkheden om conflicten te vermijden zijn in Amsterdam groot. De collectiviteit is diffuus en vooral onder hen die al wat langer in Nederland zijn, zijn er slechts weinigen die echt op de H.S. groepering zijn aangewezen.

Over het algemeen zijn het vooral diegenen die door een korte verblijfsduur of door contact-stoornissen met de Nederlandse omgeving weinig contact hebben buiten de collectiviteit en zij die naar een zeker leiderschap streven, voor wie de gezamenlijke activiteiten belangrijk zijn. Veel interne spanningen houden dan ook zichtbaar verband met het streven naar dominantie. Zulke botsingen van elkaar tegenstrevende leiders of cliques van leiders zijn er o.m. de oorzaak van dat de verenigingen nogal eens splitsen en verdwijnen. Een lid met duidelijke leiders-aspiraties zal, als hij of $z$ 'n medestanders er niet in slagen de dominantie te verkrijgen, 
zijn belangstelling verliezen en zich afzijdig houden. Als er zich een kans voordoet zal hij via een ander initiatief op de voorgrond trachten te treden. Daar niet alle adspirant-leiders even capabel zijn, leiden deze wrijvingen dikwijls meer tot afbraak dan tot opbouw van gezamenlijke activiteiten. De roddel als middel tot sociale controle wordt in deze conflicten veelvuldig als wapen gehanteerd. Ten dele loopt dit via Suriname: er vindt een soms uiterst levendige briefwisseling plaats waarbij niet zelden aan bijv. ouders of hoge partijgenoten al dan niet ware mededelingen over deze of gene worden gedaan. Daar leiderschap niet alleen volgelingen en een zekere achting impliceert maar ook tegenstanders en een zekere afkeer, richt zich de roddel dikwijls juist tegen leiders en adspirant-leiders.

Een andere tegenstelling, al moet die meer gezien worden als distantie dan als conflict, heb ik aangetroffen tussen Islamieten en Hindoes. Oorspronkelijk voerde ik deze distantie geheel terug op familiebanden. Waar familiebanden erg belangrijk zijn en de partnerkeuze bij huwelijken sterk door religie beïnvloedt wordt, vindt men bijv. in de bezoekcontacten uiteraard ook een configuratie naar religie 19 . Een andere gewichtige factor is echter het duidelijke Hindoe-karakter van beide politieke partijen, die hier zo'n belangrijke rol spelen. De partijgenoten ontkennen dit zeker als er rechtstreeks naar gevraagd wordt. Maar in vrijwel iedere toespraak treft men een verwijzing aan naar het Hindoe-karakter. Wellicht nog duidelijker is dat ik geen enkele toespraak gehoord heb, waarin een poging werd gedaan om naar symbolen te verwijzen waarmede ook de Moslims zich zouden kunnen identificeren. Deze identificatie is er dan ook niet en daarmede staan de Moslims wat terzijde. Echte conflicten op dit punt heb ik in Amsterdam overigens niet aangetroffen, al liet men zich in individuele gesprekken over en weer niet altijd even vleiend uit.

\section{INVLOED VAN DE NEDERLANDSE SAMENLEVING}

\section{a. Algemeen}

De Nederlandse samenleving oefent op het gedrag der H.S. in Nederland uiteraard een grote invloed uit. Zij dwingt eenvoudig een aantal gedragsveranderingen af. Maar dat wil nog niet zeggen dat deze veranderingen ook innerlijk aanvaard worden. De cognitieve aanpassing impliceert nog geen evaluatieve; weten welk gedrag in bepaalde situaties vereist wordt wil nog niet zeggen, dat men dit gedrag ook voor juist houdt. Dit fase-verschil in beïn- 
vloeding door en aanpassing aan de cultuur van het omringende land is niet zo verrassend. Maar bij de H.S. heb ik ook veelvuldig een fase-verschil tussen normatief en feitelijk gedrag aangetroffen, waarbij het gedrag verder (duidelijker) afweek van het Nederlandse gedrag dan de verbaal geuite norm. Soms is het blijkbaar gemakkelijker de waarden van een samenleving over te nemen dan het daarbij passende gedrag. Een voorbeeld kan dit verduidelijken. De Surinamers, ook de H.S., zijn in het algemeen geen mensen van de klok. Zoals een van hen het met zelfspot uitdrukte: "Wij, wij komen altijd te laat, maar we gaan ook weer te laat weg". Bij iedere bijeenkomst wordt iedereen weer opgeroepen op tijd te zijn; de leden zelf klagen hartgrondig over het te laat beginnen, maar niemand komt op tijd. De Nederlandse precisie en stiptheid worden wel hogelijk gewaardeerd, maar daarom nog niet nagekomen. De aanleiding tot de misverstanden die hieruit bij contact tussen Nederlanders en H.S. (kunnen) voortvloeien, kan als volgt worden omschreven: Het op tijd komen figureert bij de H.S. als waarde, bij de Nederlanders echter als norm.

In wijder verband kan gesteld worden dat de invloed van het Nederlandse normen- en waardenstelsel groot is, zonder dat het H.S. normen- en waardenstelsel daardoor zonder meer verdrongen wordt. In PARSONS' termen ${ }^{20}$ zijn beide stelsels als resp. universalistisch-specifiek en als particularistisch-diffuus te karakteriseren. Beide stelsels zijn aanwezig; niet alleen bij verschillende personen maar ook bij dezelfde personen. Het hangt min of meer van de situatie af aan welk stelsel men z'n argumenten ontleent. Een sterke universalistische ideologie b.v. bij de leden van 'Retorica', waardoor ik zelf gemakkelijk binnen kwam, nam niet weg dat de meerderheid van de leden zijn contacten particularistisch koos en daar ook wel argumenten voor kon aanvoeren. Bij conflicten gebeurt het niet zelden dat de beide partijen zich op andere waardenstelsels gaan beroepen. Zo worden de georganiseerde activiteiten door de informele leiders met behulp van bijdragen e.d. min of meer op privé-basis gefinancieerd, waarbij het nooit helemaal duidelijk is, hoeveel zij daar nu op verdienen dan wel toeleggen. Dit past typisch bij een diffuse rolverwachting. Tegenstanders beriepen zich bij een conflict, waarbij de financiële aspecten een rol speelden, echter op de Nederlandse, specifieke rolverwachting, waarin dit gedrag als corrupt bestempeld wordt 21 . Welke conceptie op een gegeven ogenblik door een bepaald persoon aanvaard wordt, is sterk afhankelijk van zijn positie ten opzichte van de personen die in het geding zijn. Ook in individuele gesprekken 
kwam men soms tot uitspraken, die in een opmerkelijke tegenstelling stonden tot wat vroeger beweerd was.

Slechts enkele keren heb ik het experiment beproefd om goede bekenden te confronteren met hun eigen tegenstrijdige uitspraken of inconsequent gedrag. Van twee personen kreeg ik daarbij de stellige indruk, dat zij zich het meten met twee maten wel bewust waren. Maar in het derde geval ontstond een uitermate pijnlijke verwarring.

In enkele gevallen bleken de klachten waarmede men zich tot mij richtte over ondervonden discriminatie te berusten op de verwarring tussen de twee normenstelsels. Zo had één van mijn kennissen een bijzonder goede verhouding met zijn werkgever. Op een avond kwam hij emotioneel geladen bij me omdat hij gediscrimineerd werd. Het bleek dat hij een bepaald voorrecht gevraagd had, dat door zijn baas geweigerd was. In dit geval had de goede arbeidsverhouding geleid tot een diffuse rolverwachting waaraan waarschijnlijk geen enkele Nederlandse werkgever zou hebben beantwoord.

\section{b. De terugkeer}

Een punt waar de voortdurende invloed van de Nederlandse omgeving zich nog het duidelijkst laat aflezen is de houding ten opzichte van de terugkeer naar Suriname. Hoewel er onder de H.S. geen migratie-traditie bestaat die vergelijkbaar is met die van de C.S., begint het probleem zich ook bij de H.S. voor te doen. Zolang er weinig H.S. in Amsterdam waren, die (vrijwel) allen nog slechts enkele jaren in Nederland verbleven, kon men het ideaal van de terugkeer levendig houden. Hoe groter de aantallen worden, hoe moeilijker de sociale controle wordt. Een sterke band met de eigen landgenoten, het levendig houden van traditie's e.d. heeft bij een langere verblijfsduur alleen zin voor hen, die inderdaad terugkeren. Zij die - om welke reden dan ook - liever in Nederland verblijven dan in Suriname, raken minder geïnteresseerd. Zelfs wel eens geïrriteerd door de voortdurende confrontatie met de eis tot terugkeer, en zij vermijden al te veel contact. De leiders staan tegenover dit verschijnsel in feite machteloos. Veelal richten deze mensen zich in persoonlijke gesprekken juist uitermate fel tegen deze leiders, die men beschuldigt van corruptie, geïntrigeer en Streberei. Men is dan zover overgegaan van de particularistisch-diffuse naar de universalistisch-specifieke opvatting van de leidersrol, dat men zich bewust afkeert. De meesten blijven de terugkeer wel als vaag ideaal koesteren. Maar dikwijls 
stuit men op zulke hoge eisen ten aanzien van het beroep dat men in Suriname wenst uit te oefenen, dat de gedachte opkomt dat hier al bij voorbaat een excuus geschapen wordt om niet terug te keren.

Er wordt door de H.S. onderling veel gesproken over het gevaar van assimilatie. Men vreest daarvan in religieus-culturele zin vooral het loslaten van de traditie zoals die ten aanzien van het gezinsleven bestaat. In politieke zin vreest men (vooral de leiders uiteraard) het verlies van (potentiële) aanhang. Dit leidt ertoe dat grote en kleine leiders op de noodzaak tot terugkeer voortdurend de nadruk leggen ${ }^{22}$. Het is voor de leiders ook zelf een voortdurend dilemma. Zolang men nog een welomschreven studie of opleiding volgt, vormt het geen probleem. Maar de positie van hen die werken of niet (meer) studeren wordt bij een langere verblijfsduur hoe langer hoe zwakker. Het wordt dan vrijwel onmogelijk tegenover de jongeren c.q. pas aangekomenen, die over het algemeen de terugkeer sterk beklemtonen, een legitieme basis voor leiderschap te vinden. $\mathrm{Na}$ enige tijd staan een dergelijke leider nog maar twee wegen open: òf z'n leidersrol opgeven en in Nederland blijven, òf terugkeer naar Suriname om daar te pogen tot een zekere prominentie te geraken. Van beide mogelijkheden wordt gebruik gemaakt.

De drang tot terugkeer onder de H.S. is (op het ogenblik) groter dan onder de C.S. In de eerste plaats is de groepering kleiner en de traditie korter zodat er meer onderling contact is. In de tweede plaats zijn de stijgingskansen van H.S. die in Nederland een studie hebben gevolgd, groter in Suriname dan voor de C.S. Dit komt door de zuilenachtige ontwikkeling van de Surinaamse maatschappij en de achterstand, die de H.S. nog hebben in aantal geschoolden van allerlei aard.

In de derde plaats is de binding aan de familie, met name aan de ouders, bij de H.S. groter dan bij de C.S. In deze context is het weinig verwonderlijk dat de terugkeer als een waarde geldt, die slechts door weinigen wordt aangevochten. Maar de beklemtoning van deze waarde is niet los te zien van de constatering, dat deze terugkeer niet langer een vanzelfsprekende verwachting is en mede juist daarom als norm moet worden gehandhaafd.

\section{c. Godsdienst}

De invloed van de Nederlandse samenleving in de richting van rationalisatie en secularisatie is groot. Zo groot, dat ook de ver- 
dedigingswijze erdoor beïnvloed wordt. Waar men enerzijds de nadruk legt op eigen traditie en godsdienst, tracht men anderzijds uit deze traditie juist die aspecten naar voren te brengen, welke zich het beste laten verenigen met het moderne Westerse leven. Men beklemtoont waarden als geweldloosheid, tolerantie, schetst kortom een beeld van het Hinduisme, zoals dat in bepaalde kringen in het Westen altijd veel waardering heeft gevonden. Ook op het practische nut van bepaalde al dan niet religieuze voorschriften en gebruiken wordt graag gewezen. Niemand wil 'orthodox', dat zo ongeveer synoniem is met 'ouderwets', zijn. Maar het grote probleem daarbij is, dat het Hinduïsme zich niet zo gemakkelijk voor een modernistische benadering leent. De reden hiervoor is m.i. de verwevenheid van de religie met de vormgeving van het dagelijkse leven, waarbij veel minder dan bij het Christendom en de Islam ook een rationeel opgebouwde theologie voorhanden is. Het was voor mijn informanten dan ook vrijwel onmogelijk om met mij over religieuze voorstellingen en ideeën te spreken. Zelfs zij die zich zelf als vurige en oprechte Hindu's beschouwen en door opleiding en intelligentie zeer wel in staat waren hun houdingen, gevoelens etc. onder woorden te brengen, konden zich op dit punt maar uiterst moeilijk uitdrukken. Men vlucht terug in "Ik ben nu eenmaal zo groot gebracht" of "Dat is onze gewoonte". Dit leidt tot een zekere ambivalentie ten opzichte van de eigen religiositeit.

Enerzijds dwingt de confrontatie met de Nederlandse omgeving ertoe om de waarde van de eigen culturele traditie belangrijk te achten. Anderzijds dwingt de invloed van de Nederlandse omgeving er ook toe, dat godsdienstige voorstellingen en ideeën in hoge mate rationeel benaderd worden. Met name wordt verwacht, dat men onderscheid weet te maken tussen hoofd- en bijzaken; tussen religieuze verplichtingen en cultureel bepaalde gewoonten. Dit onderscheid nu maken de H.S. niet. Het duidelijkst sprak dit bij de discussies over voedingsgewoonten. Als bij ons thuis gegeten werd, hield mijn vrouw uiteraard rekening met de gebruiken van de gasten. Het niet eten van rundvlees werd door ons aanvankelijk als een zuiver religieuze verplichting gezien. $\mathrm{Al}$ onze $\mathrm{H}$.S. vrienden verwierpen echter deze religieuze betekenis wat henzelf betrof. "Je denkt toch niet, dat $i k$ geloof dat een koe heilig is" riep één van hen verontwaardigd uit. Ook bij de onlusten in India naar aanleiding van het slachten van koeien, keerden mijn H.S. vrienden zich unaniem tegen de 'orthodoxe fanatici'. Toch handhaafden bijna al deze mensen hun gewoonten, 
wat voor velen in Nederland echt wel last en moeite met zich mee bracht. Het aanpassingsprobleem op dit punt lag echter niet zozeer op het tweede niveau (normen en waarden) als wel op het derde niveau (smaak/esthetica). Nog beter is het waarschijnlijk het anders te formuleren: het onderscheid tussen deze niveau's was voor de H.S. op deze punten niet relevant.

Verschillende H.S. interpreteren de trouw aan de religieuze sociale gebruiken ook alleen maar als sociale conformiteit. In vertrouwen vertelden zij dat het alleen maar was omdat men tegenover elkaar niet durfde, daar er altijd wel iemand was die het rondvertelde, etc. "Laat mij je zeggen" aldus een informant "dat iedere Hindu best een stukje worst lust, als hij maar zeker weet, dat hij alleen is". Hoewel de hypocrisie in deze uitlating bepaald overschat wordt, is er inderdaad ook wel sprake van een zekere sociale dwang, waar verschillende individuen zich niet dan ongaarne onder schikken! Daarbij heeft het handhaven van bepaalde gewoonten en tradities - los van hun religieuze oorsprong - op zichzelf een zekere waarde verkregen als symbool van de interne integratie van de H.S. tegenover de omgeving. Het grote ongenoegen dat er echter ook heerste, de uiterst felle veroordelingen van bepaalde praktijken waartoe men plotseling kon overgaan, wijzen er m.i. op, dat het Hinduïsme van de H.S. de invloed van het moderne levenspatroon niet werkelijk heeft kunnen verwerken. Het is dan ook bij vele H.S. in Nederland niet meer dan een betrekkelijk willekeurig aantal gewoonten en gebruiken, waar men om emotionele redenen aan vasthoudt, maar die geen religieuze betekenis hebben.

De Islamitische H.S. hadden het in dit opzicht gemakkelijker. Voor hen waren de lijnen scherper getrokken. De Islam als rationeler opgebouwde godsdienst laat zich m.i. ook gemakkelijker inpassen in het moderne westerse leven. Toen men merkte dat ik wel eens vroeg naar religieuze opvattingen en gebruiken, kwamen er ook al snel uitnodigingen om op bepaalde feestdagen mee te gaan naar de Moskee in Den Haag. Een van mijn vrienden beschikte zelfs over een boekje waarin aan Christenen de Islam werd uitgelegd. Hij dreigde daar een welhaast al te overvloedig gebruik van te maken. $\mathrm{Nu}$ wil ik niet de indruk wekken dat er absolute verschillen tussen beide godsdiensten bestaan in de aanpassing aan de Nederlandse omgeving. Ook onder de Moslems zijn er, die in hoge mate van hun eigen opvoeding vervreemd zijn, zonder dat ze daar een duidelijk (nieuw) alternatief tegenover kunnen stellen. Maar de graduele verschillen zijn onmiskenbaar.

\section{d. Gezin/familie}

Het huwelijks- en gezinsleven wordt door de H.S. zelf beschouwd als de hoeksteen van de H.S. traditie ${ }^{23}$. Hoe deze hoeksteen zich zou houden in de migratie-situatie had derhalve mijn belangstelling. Materiaal erover heb ik echter slechts schaars kunnen verzamelen. Het aantal H.S. is al niet groot in Amsterdam en van hen, die deel namen aan de georganiseerde activiteiten, waren de meesten ongehuwd. 
Eén observatie kan echter moeilijk niet gemaakt worden: de naar Nederlandse maatstaven hoge mate van separatie tussen mannen en vrouwen. Dit komt tot uitdrukking bij de gescheiden vrijetijdsbesteding en de strikte, hiërarchische rol-separatie tussen echtgenoot en echtgenote. Men is zich van het 'gezamenlijk uitgaan'-patroon wel bewust, beschouwt het ook als modern en ontwikkeld, maar de meesten komen er zelf niet toe. In gesprekken met mannen zeiden dezen dat hun vrouw dat zelf ook niet wilde, dat zij nu eenmaal niet gewend was zich in het openbaar te bewegen, dat ik dat niet moest vergelijken met mijn vrouw die ontwikkeld was e.d. Wat hiervan precies waar was weet ik niet, een stuk rationalisatie zit er zeker in.

Ik heb op dit punt ook enkele vrouwen ondervraagd. Eén van hen aanvaardde (althans verbaal) het mannen bij mannen-principe tot op grote hoogte. De anderen waren duidelijk ontevredener. Opvallend was, dat zij daarbij uitdrukkingen gebruikten als: "Nederland heeft mijn ogen geopend". Zij meenden dat zij in vergelijking met de man te hard moesten werken, dat hij tijdens zijn vrije uren te veel geld uitgaf en haar te veel thuis liet zitten. In de Nederlandse samenleving, waar anders dan in Suriname de H.S.-vrouw of meisje nu niet zo zeer een eigen 'ambience' heeft, is het voor de vrouwen ook wel heel moeilijk zich niet aan het Nederlandse patroon van gezamenlijke vrijetijdsbesteding te refereren. (Er zijn trouwens ook mannen, die dit doen en hun vrouw meenemen. Ze behoren nu niet tot de actiefste deelnemers aan H.S. activiteiten!).

Het zelfde geldt voor de grotere vrijheden, die de man in het verkeer tussen de sexen in de H.S.-traditie van oudsher toekomen. Ook daar kan het moeilijk anders dan dat de vrouwen zich positief op de Nederlandse omgeving richten.

Op één punt heb ik wat meer gegevens namelijk daar waar het gemengde huwelijken of voornemens daartoe bestaan. De invloed van de mede uit vrouwen bestaande Nederlandse samenleving op de ongehuwde mannen die van de H.S. een belangrijk deel uit maken, zal op dit punt nauwelijks adstructie behoeven. Maar men moet daarbij niet alleen denken aan de contacten met Nederlandse meisjes en daaruit eventueel voortvloeiende huwelijken. Het raakt ook degene die niet trouwt of al getrouwd is, omdat het gemengde huwen met grote emotionaliteit beladen is. Vandaar dat men tegenover mij - zelf gemengd gehuwd - dit onderwerp nogal eens ter sprake bracht. De oppositie van de zijde der ouders is groot en niet zelden van een directheid tegen de betrokken 
partner, die naar het Nederlandse gevoel ongehoord is. Deze oppositie houdt niet op als het huwelijk eenmaal gesloten is, zoals in Nederland nogal eens gebeurt als de ouders er zich niet mee verenigen kunnen. Ook na de huwelijkssluiting wordt er wel onverbloemd op aangedrongen te scheiden en 'beter' te trouwen. Tegelijkertijd dringt vanuit de Nederlandse omgeving de geheel andere opvatting door, waarbij de verantwoordelijkheid voor de keus (volledig) bij de partners ligt. Dit tezamen met de algemene verschuiving van het waardenpatroon in de richting van universalisme makkt het velen uiterst moeilijk te beslissen en als eenmaal een beslissing genomen is zich er dan ook aan te houden.

Het komt voor dat jongeren, die jarenlang een vaste, intieme relatie met een Nederlands meisje onderhouden, plotseling tijdens een vakantie in Suriname trouwen. Bij terugkomst ontvangen vrienden en kennissen hem dan uiterst koel. $\mathrm{Zij}$ hebben de plotselinge verschuiving in kracht van milieu-invloed uiteraard niet meegemaakt en beoordelen de situatie niet vanuit de strikt particularistisch-diffuse waardenoriëntatie ten opzichte van het ouderlijk gezag, op grond waarvan de plotselinge beslissing genomen is. Dit soort voor beide betrokken vrouwen en de man uiterst dramatische gebeurtenissen, zijn gemakkelijk in morele termen als kwade trouw e.d. te interpreteren, vooral als de beslissing totaal onverwacht komt. Maar sociologisch kan de plotselinge besluitvorming beter als een noodsprong worden gezien; als een soort 'vlucht' uit een cultuurconflict, dat de betrokkene niet heeft kunnen oplossen. Dit cultuur-conflict is kenmerkend voor de H.S. in Nederland, die zowel hun tradities willen behouden en zichzelf willen blijven, als willen moderniseren en aanpassen bij de moderne eisen, zonder dat men daarbij (op het ogenblik al) tot een goede synthese weet te komen.

\section{Positiebepaling t.o.v. DE andere Surinamers in Neder- LAND}

Of men eenheid of verscheidenheid waarneemt, hangt in hoge mate af van de positie welke de waarnemer inneemt. Tegenover de Nederlandse omgeving zijn de overeenkomsten tussen de verschillende categorieën Surinamers in Nederland groter, véél groter dan de verschillen. Het is voor de Nederlandse waarnemer dan ook des te opmerkelijker als hij onder de H.S. zelf een perceptie van duidelijke sociale afstand tot de Creoolse Surinamers bespeurt ${ }^{24}$. In enkele gevallen zelfs zo zeer dat H.S. zelf zeiden dat 
de afstand tot Nederlanders kleiner was dan tot C.S. Algemeen is echter dat men bij een duidelijk gevoel van distantie toch ook een grote behoefte heeft aan contact. Een contact dat in de informele sfeer dan ook plaatsvindt, al is het relatief weinig. Veel opvallender is het gebrek aan gezamenlijke deelneming aan al dan niet gezamenlijk georganiseerde activiteiten. Het onderwerp wekt diepe hartstochten en gezien de grote toegeeflijkheid wat betreft het verbaal uiten van agressie in het gemeenschappelijke Surinaamse cultuurpatroon, kan menige krachtige uitspraak worden vernomen. Men vergat daarbij blijkbaar gemakkelijk dat de onderzoeker door affectieve banden aan de C.S.-groepering verbonden was en daarmede toch ook een zekere ervaring had opgedaan. Overigens biedt het bestaan van een zekere stereotype voorstelling over en weer weinig reden tot verklaring waarom men elkaar ook in den vreemde kennelijk zo moeilijk kan vinden. Voor Amsterdam zijn daarvoor een aantal factoren aan te wijzen, factoren overigens, die zeker niet zonder meer op andere plaatsen kunnen worden betrokken.

Amsterdam is groot, de mogelijkheden om zich aan contacten te onttrekken zijn voor degenen die dat willen duidelijk aanwezig. Wil men iets organiseren, dan moet men beschikken over adressen. De Surinamers zijn veelal inwonend en alle inwonenden verhuizen veel. $Z_{0}$ is het bijzonder moeilijk onder deze sterk fluctuerende bevolking een organisatie op te bouwen. Dit geldt voor alle Surinamers; het geldt ook voor de H.S. We hebben dan ook gezien dat een bepaald type leider nodig is om nog een zekere organisatie-graad te kunnen bereiken. Juist deze leiders hebben een zeker belang bij het handhaven van de sociale afstand tot de andere Surinamers, omdat hun leiderschap een specifiek H.S.karakter heeft. Nu moet men ook weer niet te veel aan de boze wil van de leiders toeschrijven, want zij zijn weer afhankelijk van een aantal specifieke factoren, die juist hen als leiders naar voren doen treden.

Ten eerste is dat de grote rol die de verwantschap speelt bij de contactlegging.

Ten tweede de zeer sterke behoefte (bij een korte verblijfsduur) aan een eigen omgeving, waarbij het derde niveau van aanpassing (esthica/smaak) een grote rol speelt.

Ten derde een specifiek mannelijk patroon van vrijetijdsbesteding waarbij met name het dansen, dat van de Creoolse feesten zo'n belangrijk bestanddeel vormt, niet of weinig gewaardeerd wordt. 
Ten vierde, het sterke gevoel in Suriname tot een nog niet (volledig) geëmancipeerde minderheid te behoren, die de rijen gesloten moet houden om de volledige emancipatie te bereiken.

Op al deze punten is de acculturatie in Suriname zelf nog te weinig voortgeschreden dan dat er in Nederland voldoende gemeenschappelijke achtergrond is om op terug te vallen. Een ander deel van de verklaring moet gezocht worden in de eigenschappen van de C.S. in Amsterdam.

In de eerste plaats moet dan het karakter van de Surinaamse verenigingen in Amsterdam genoemd worden. Op het ogenblik functioneren deze verenigingen niet, maar in het recente verleden hebben bijv. 'Ons Suriname' en de daarmee nauw gelieerde verenigingen als de VSSA een bloeiend bestaan geleid. Al deze georganiseerde activiteiten waren, net als die van de H.S. op een bepaalde manier met de Surinaamse politiek verbonden. De leiders manifesteerden zich derhalve in de eerste plaats als politieke tegenstanders. Bovendien streefden de uit het studentenmilieu afkomstige leiders van deze verenigingen er met nadruk naar om zich ook in het arbeiders-milieu een zeker leiderschap te verwerven. Maar het revolutionaire, in ieder geval radicale karakter was nu juist bij uitstek ongeschikt om ook de H.S. te integreren. "Zij verwijten ons onze partijen, maar zij mogen hun partijen houden", is een stereotype klacht ${ }^{25}$. De sterk symbolische waarde die een man als NkRuma een tijdlang voor deze Creoolse jongeren had, versterkte het idee, dat 'ze van Suriname een negerland willen maken'. $\mathrm{Nu}$ de identificatie is verschoven van NKRUMA naar CASTRo is het niet bij voorbaat uitgesloten dat men tot een gemeenschappelijk symbool kan komen. De romantische figuur van CASTRO zal wel niemand uit het Caraïbisch gebied geheel onberoerd laten. Een typische identificatie-figuur is hij voor de H.S. echter zeker niet.

Hoewel ik er persoonlijk van overtuigd ben dat de radicale Creoolse leiders in Amsterdam oprecht streefden naar multiraciale partijvorming, heb ik onder de H.S. op dit punt weinig anders dan wantrouwen gevonden. Het leiderschap heeft ten aanzien van de H.S. dan ook duidelijk gefaald.

De voornaamste reden hiervoor is wellicht eenvoudig gebrek aan kennis. Een van de H.S. zei mij eens: "Kijk, wij kennen de Creolen wel, want de kleinen kennen de bazen wel; maar de baas kent de kleinen niet". Deze uitspraak leek mij sterk overdreven. Maar om de proef op de som te nemen begon ik een aantal C.S. studenten betrekkelijk eenvoudige feitelijkheden te vragen over 
de H.S. in Suriname. Ik moest daarna wel toegeven dat deze kennis inderdaad miniem was. Geringer dan de kennis der H.S. over de C.S., hoewel ook hier stereotypen en vertekeningen niet ontbreken. Met name op school heeft de H.S. zich via medeleerlingen en onderwijzend personeel een beeld der C.S. gevormd. Wat de oorzaken daarvan ook mogen zijn (wellicht separatie stad - platteland) kan thans verder terzijde blijven. Het gaat er hier slechts om aan te geven wat een oorzaak van het falen op dit punt van bepaalde leiders geweest kan zijn.

Een andere reden is het minderheidsgevoel der H.S., waardoor men in vergaderingen altijd het gevoel had en heeft - en uit eigen ervaring moet ik zeggen niet zonder grond - dat men toch altijd overstemd wordt. Dus komt men maar helemaal niet meer. Uiterst belangrijk is waarschijnlijk ook het onvermogen van wat ik nu maar als 'linkse leiders' zal aanduiden om verstandig te reageren op sociale afstand. Agressieve veroordelingen en beschuldigingen van 'racisme' lossen uiteraard weinig op. Voor de H.S. voor wie, ook zonder racist te zijn, in bijna alle gevallen de ervaring van een zekere sociale afstand een levenservaring is, is dat voldoende om zich verder afzijdig te houden. Deze afzijdigheid - in zeker opzicht zelfs vijandigheid - neemt niet weg, dat men ook duidelijke behoefte aan contact heeft. Men ziet heel goed in dat alle Surinamers in hoge mate lotsverbonden zijn. Bovendien, zoals al eerder gezegd, staat men ambivalent ten opzichte van de eigen traditie. Enerzijds wil men haar behouden om geen 'niemand' te worden, anderzijds wijst men intern 'orthodoxie' in hoge mate af. Wel hebben de H.S., zoals zoveel zich geëmancipeerd hebbende minderheidsgroepen, een zekere overgevoeligheid voor alles wat zij zien als aantasting van hun rechten en waardigheid.

Een grotere participatie in Surinaamse activiteiten in Amsterdam wordt belemmerd door inderdaad niet geringe moeilijkheden, die echter m.i. primair van tactische aard zijn. Het opkomen van een nieuwe vereniging of een nieuwe leidersfiguur, die deze moeilijkheden de baas kan, zou in de toekomst zeker tot een sterkere participatie der H.S. kunnen leiden.

\section{AANTEKENINGEN}

I. Deze bloei was tijdens mijn onderzoek overigens al aan het tanen.

2. Omtrent de rol van de participerende waarnemer zie:

Lammers, C. J.: De participerende waarneming. Sociol. Gids 7, 1960, p. 204 \}e.v. 
In hoeverre de onderzoeker groepslid moet zijn om te kunnen spreken van participerende waarneming is niet helemaal vast te stellen. Zo spreekt Corrie H. RIEDEMAN van een participerend waarnemen bij de Lougroep (Sociol. Gids 7, 1960, p. 225) waarbij zeer expliciet geen rol binnen de groep werd aangenomen.

3. Deze problematiek is niet onbekend. Men zie bijv. Lammers op. cit. Men vergelijke ook:

Whyte, William F.: Street Corner Society, Univ. of Chicago Press Paperback, I966, in het bijzonder p. 342 e.v. (I e dr. 1943).

4. Gunawan, B.: Indonesische Studenten in Nederland. Den Haag 1966, p. 4 . Patterson, Sheila: Dark Strangers, Pelican Book A 716, Hfd. I.

5. Doorn, J. A. A. van \& Lammers, C. J.: Moderne Sociologie. Aula boek 29, p. I50-I 52. Collectiviteit: een groepering waarvan de leden t.a.v. relevante punten solidair zijn, t.o.v. elkaar op grond van gemeenschappelijke waarden.

6. Gunawan op. cit. Hfd. III. Men vergelijke ook zijn weergave van de onderzoekingen van Garigue \& WeBster en van CAREY p. 5, en Patterson op. cit. bijv. p. 28-34.

7. Ik steun hierbij in belangrijke mate op: Ellemers, J. E.: Immigratieproblemen. Sociaal wetenschappelijke Verkenningen. Assen, 1957.

8. Een globaal overzicht van deze migratie biedt: Amersfoort, J. M. M. van: Surinamers in de lage landen. Den Haag 1968.

9. Alle Surinamers rekenen niet alleen een veel groter aantal mensen tot hun verwanten dan bijv. Nederlanders, zij ontlenen daaraan ook zekere rechten en verplichtingen. Bij de C.S. zijn noch het toerekenen van de verwantschap, noch de daaruit voortvloeiende verplichtingen gemakkelijk weer te geven. Buiten de directe verwanten heeft men vele 'neven': een niet te omlijnen categorie met wie men zich in relatie acht. De kennis van de verwantschapsrelaties bij de H.S. is veel groter. Men kan meestal precies aangeven via welke personen men met een bepaalde persoon verwant is. Ook tussen naar Nederlandse maatstaven verre verwanten trof ik in Amsterdam duidelijke betrekkingen aan, zich uitend bijv. in bezoek-contacten, hulp bij het zoeken van een kamer etc. Overigens trof ik bij de H.S. ook enkele malen het vagere C.S.-gebruik van het woord 'neef' aan.

ro. De vroegere Verenigde Hindostaanse Partij. De grootste van de Hindostaanse politieke partijen in Suriname. De tegenwoordige naam luidt: 'Vatan Hitkari Partij' (Partij ter bevordering van het National Welzijn).

II. Kleine Hindostaanse Partij in Suriname, die in sterke rivaliteit leeft met de VHP, waarvan hij een afsplitsing is.

12. Na de ontwikkelingen van februari 1969 is in de verhouding tussen Actie-groep en VHP een wijziging gekomen. Beide steunen het huidige kabinet MAY tegen de oppositie van de NPS.

13. Deze verbinding tussen politieke partij en religieuze richting is bij nader inzien een betrekkelijk toevallig locaal Amsterdams gegeven. Ik ging er vanuit dat de H.S. dit onderscheid vanuit Suriname, dat ik slechts uit de literatuur ken, hadden meegebracht. Dr. J. H. ADHIN 


\section{I38 HINDOSTAANSE SURINAMERS IN AMSTERDAM}

heeft mij er echter in een gedocumenteerde schriftelijke mededeling op gewezen, dat dit niet het geval is. Ik vermoed dat in de kleine Amsterdamse groep de familie-relaties als nevenverschijnsel dit verband tussen politieke voorkeur en religieuze richting bewerkten.

I4. Wellicht alleen voor hen die vertrouwd zijn met twee boeken, die mij hier zeer te stade zijn gekomen; nl.: Whyte, op. cit., en

Homans, G. C.: The Human Group. London 1951.

15. Gunawan, op. cit. p. 79 .

16. Ook hier is de parallel met Gunawan opvallend. Men vergelijke p. 73.

17. Gunawan, op. cit. p. II3-II4.

18. Vereniging voor Surinaamse Studenten Amsterdam.

19. Voor de sterke voorkeur voor een huwelijkspartner uit de eigen religieuze kring onder de H.S. zie:

Speckmann, J. D.: Marriage and Kinship among the Indians in Surinam. Assen 1965, p. I19-120.

2o. Parsons, Talcott: The Social System. Glencoe, (Ill) $195 \mathrm{I}$, in het bijzonder p. 58-67 en IOI-II2.

2I. De basis voor het conflict is in feite dezelfde als bij het conflict tussen Krantz en Vercruysse en de leiding van de door hen gechaperonneerde Rock en Roll-club; bij de H.S. speelt het zich echter af bij de leden onderling. Men zie:

VERCRUYSSE, E. V. W.: Het ontwerpen van een sociologisch onderzoek. Assen ze herziene druk 1966, p. 37.

De (officiële) Nederlandse rolverwachting is dat een leider van een ontspanningsvereniging dit uit liefhebberij en altruïsme doet en er zeker financieel niet beter op wordt. Zowel de Rock en Rollers als de H.S. daarentegen vinden het min of meer vanzelfsprekend, dat men 'er iets aan over houdt'.

22. "Want als gij hier zijt, en ge zijt niet van plan terug te keren naar uw land, dan zijt gij geen goede vaderlander."

LAchmon, J. H., voorzitter van de VHP. Toespraak te Amsterdam, 5 mei 1968.

23. $\mathrm{Zij}$ zijn het in dit opzicht eens met de sociologen; zie ook: SPECKMANN, op. cit., bijv. p. I30-I3I.

24. Men vergelijke:

OedAYRAJSINGH VARMa, C. C. S. : Een sociometrisch onderzoek naar de ethnische factor bij de keuze van klasgenoten op enkele scholen in Suriname. Sociol. Gids I5, no. 6, I968.

In dit artikel, dat ik pas na het schrijven van dit verslag onder ogen kreeg, lijkt mij vooral hetgeen vermeld wordt over de resultaten op de Mulo-school (p. 275) in dit verband van belang.

25. Bedoeld zijn respectievelijk VHP/Actie-groep en NPS/PNR. 